\title{
TRAVEL MODELS FOR CORRIDORS OF METROPOLITAN AREAS SERVED BY RAILWAYS
}

\author{
A. BRZEZIŃSKI ${ }^{1}$, K. JESIONKIEWICZ-NIEDZIŃSKA
}

\begin{abstract}
In recent years adverse processes of suburbanization have been observed in cities. It has become a serious challenge for urban and transport planners, as it influences largely the quality of space, the quality of life, and the cost of running the city. This paper is dedicated to travel models in areas serviced by a railway system, and is based on a real-life survey example of the Błonie community, a district belonging to the Warsaw metropolitan area. Research carried out in 2014 focused on combined travels behaviors recorded using GPS locators as well as quantitative research (volumes of users across various transport systems).
\end{abstract}

Keywords: trip modeling, traffic analysis, travel chains, combined travel, public transport, speed and travel length, suburbanization.

\section{INTRODUCTION}

Initially, rail transport played the role of the main stimulator of settlements located some distance from large cities, becoming an important factor in shaping metropolitan areas. Railway stations and stops created an interest in compact housing complexes and walking distance, limiting the locations and scale of the newfound suburbs in a natural way. Along with the development of individual motorization, the importance of the railway declined, beginning a period of uncontrolled development of cities as a consequence of the high urgency put on the development of road systems. Ongoing processes of motorization alongside road infrastructure improvement have made

\footnotetext{
${ }^{1} \mathrm{PhD}$. Eng., Assistant professor, Warsaw University of Technology, Faculty of Civil Engineering, office 645, al. Armii Ludowej 16,00-637, Warsaw, Poland, a.brzezinski@il.pw.edu.pl

${ }^{2}$ M.Sc Eng., Warsaw University of Technology, Faculty of Civil Engineering, office 646, al. Armii Ludowej 16, 00-637, Warsaw, Poland, k.jesionkiewicz@il.pw.edu.pl
} 
attempts to solve this unfavorable situation, through an increase of appeal of public transport offers, for one. This is caused by a dispersion of residential housing, which is notable enough to make public transport uncompetitive and unprofitable due to high operation costs and relatively low volumes. Integration of both transport systems still stands a chance, for example through reliance on individual transport in areas with low numbers of private homes (when commutes are scattered throughout the area), and an emphasis on public transport where its efficiency is justified by the number of travelers (where commutes are concentrated in the given transport corridor). This leads to the formation of complex travel models connected with transfers between different transport modes, these so-called combined travels, allowing more efficient use of existing transport systems and, in particular, public transport subsystems.

\section{ANALYSIS AND SYNTHESIS OF LITERATURE}

Study of transport behavior is essential for planning the development of metropolitan areas. Appropriate identification of travel behaviors and recognition of their phenomena allow for the construction of travel models and for forecasting and consequential planning and design of transport systems and proper transport system organization. This issue is the point of interest in surveys carried out by research institutions and units in Poland and abroad. Most of them refer to travel within large cities, and less often metropolitan travels. Problems related to transport systems functioning in metropolitan cities in Europe and their solutions are described in [1], among others, the role of the relationship between transport and spatial planning is indicated (in the context of the distribution of the origins and destinations of travel, for example), and the role of public transport in reducing transport demand, reducing emissions, and improving transport energy efficiency. On the basis of the acquired analysis it was concluded that an increase in the share of public transport in the metropolitan travels is possible through increasing intermodality and use of road charges. A part of this research (described in [1], [2]), refers directly to travel chains and their components. In [3] the importance of skills for determining generalized cost estimates of each individual act of travel is indicated (of varying distances, from $1,5 \mathrm{up}$ to $40 \mathrm{~km}$ ) and this enables us to recognize the behavior of passengers and their choices of modes of transport. The author has brought attention to the costs of trips taken by cars, which are still competitive mainly because people do not consider public and external costs. On the basis of previous research analysis it can be concluded that this research is slightly based on detailed observations of the combination of individual trips (for example thanks to the advantages of GPS locators), which allows us to analyze travel chains via means of transport 
taking into account time, speed, or kilometers traveled; this is a special feature of the surveys described in this article.

\section{RESEARCH METHOD}

This paper presents results of surveys concerning travel models recognized in areas supported by commuter rail. They have been concentrated on direct and combined metropolitan travels taken by car, bus, and train, through the use of interviews, through quantitative research of users in a particular transport systems along railway corridors, and through continuous registration of user positions in the network using GPS (Global Positioning System) locators and obtained in this way coordinates of the sampling rate 1-5 seconds, depending on the speed of movement correlated with the information about the currently-used means of transport. These surveys were focused on commuter traffic in morning peak hours. This time range was chosen because of its direct nature of the home-to-work commute. Surveys of return trips (afternoon) were abandoned due to numerous additional destinations (such as shopping or use of other consumer services), which disturb the observation of work-to-home travel motivations. Research carried out at railway stations and bus stops allows us to compare characteristics of trips which involve transfer to public transport and direct trips taken by cars.

\section{SURVEY CASE}

As a survey subject for the analysis of metropolitan travel, the Błonie community was selected along with the railway corridor connecting Błonie with Warsaw - the main, central town of the metropolis. Błonie, with its 12,000 inhabitants in the core city alone (and 21,000 including surroundings) is one of the 36 cities belonging to the so-called OMW (Warsaw Metropolitan Area). Traveling between Błonie and Warsaw is possible by metropolitan railway, metropolitan buses, small buses (through national road No. 92), and cars (through motorway A2 and national road No. 92). Due to the distance to the central city (about $30 \mathrm{~km}$ ), the peak of metropolitan traffic occurs between 6:30-7:30 pm.

In 2013 and 2014 surveys of transport behaviors were carried out among residents of the city and public transport users [4], [5], [6]. The resulting observed number of trips from Błonie towards Warsaw was 635 during morning peak hours, with the following modal share: most trips by train $56 \%$ (355 travels), and significantly less by car $-34 \%$ (215 travels). The rest of the trips are 
attributed to buses and small buses - 10\% (165 travels). The study revealed a number of combined trips with more than one mode of transport, especially based on transfers to the rail system.

\section{RESEARCH RESULTS}

\subsection{COMBINED TRIPS USING TRAINS AND BUSES}

Surveys regarding travel between Błonie and Warsaw revealed that most transfers are connected with rail, less with buses. In the case of trips commenced by car (at travel origin), the availability of the rail system increases the probability of combined methods of travel. A well-structured metropolitan rail system is characterized by the density of origins and destinations in the immediate vicinity of the station/stop. This reduces the distance from the trip's origin point to a transfer node and favors access on foot and by bicycle. This is the case of Błonie, where surveys have shown that in morning peak hours $68 \%$ of people get to train station on foot, while taking into account the route extension factor $1.25^{3}, 94 \%$ of those journeys are in the range of $0.3 \mathrm{~km}$ to $1.6 \mathrm{~km}$, which means that the range of walking distances is considerable.

For the remaining $32 \%$ of journeys various modes of transport are used, and therefore those trips belong to the category of combined travel. Among these, car users are predominant - $28 \%$ (responsible for $88 \%$ of combined travel) with a slightly higher share of "Kiss \& Ride 4 " carpooling $-13 \%$ ( $41 \%$ of combined travel), then Park \& Ride drivers $-12 \%$ (38\% of combined travel), and Park \& Ride passengers - 3\% (9\% of combined travel). The share of bike travel amounts to $4 \%$ (12\% of combined travel). Taking into account the route extension factor, it turns out that $90 \%$ of travel by car happens in the range of $1.6 \mathrm{~km}$ to $3.1 \mathrm{~km}$. It means that the shortest car travel distances $(1.6 \mathrm{~km})$ and the longest walking distances $(1.9 \mathrm{~km})$ practically overlap. These distances significantly affect decisions concerning methods of accessing train stops, undoubtedly depending on the individual characteristics and capabilities of travelers. Noteworthy is the fact that the basic range of impact of car travel is slightly larger than $3 \mathrm{~km}$, thus quite short, and rather typical for bicycle trips, while at the same time surveys revealed that bikes are used only in $4 \%$ of combined travel. Among these, $1 \%$ of people leave their bikes at the station, and 3\% take them onto the train.

\footnotetext{
${ }^{3}$ Route extension coefficient, designated taking into account the average representative assigned to length of walk from the 4 Błonie city districts. Accepted value of the coefficient is similar to the coefficients adopted in other studies (1,21-1,40 [7]).

${ }^{4}$ Kiss \& Ride and Park \&Ride - intermodal transport systems with transfer from car to public transport, with leaving car in the parking $(\mathrm{P} \& \mathrm{R})$ and pool $(\mathrm{K} \& \mathrm{R})$.
} 
It was also observed that the length of bicycle trips is comparable to the length of car trips, remaining within the range of 1.1 to $2.7 \mathrm{~km}$.

According to a survey conducted among bus passengers, bus stops have much smaller impact than train stations. It was found that the distance to the bus stop is from $0 \mathrm{~km}$ to $1.7 \mathrm{~km}$, with most trips (61\%) within the range of up to $0.5 \mathrm{~km}$. A better availability of stops (which are closer to origins and destinations then train stations) is characteristic for bus service in Błonie. Moreover, bus stops are located in the center of the city and are evenly distributed. Undoubtedly this affects the modal share dominated by walking.

\subsection{TRAVEL CHAins}

In the surveys described in [8], six major travel chains between Błonie and Warsaw were identified: 1-segment journey by car (direct) and four multi-segmented (combined travel): walk+bus, car+train, bike+train, and walk+train. The use of GPS locators has made it possible to identify and survey more than a dozen different travel chains (single- and multi-segment), including the most popular: the 1-segment travel chain by car using national road No. 92, the 1-segment travel chain by car using motorway A2, the 3-segment travel chain: walk-bus-walk (beginning and ending with a walk to the bus stop and from the bus stop to the trip destination, including the bus ride), the 3 -segment travel chain: bike-train-bike (beginning and ending with cycling to the train station and from the train station to the end destination, including the train ride with the bike), the 4-segment travel chain: walk-train-tram-walk (beginning and ending with a walk to the train station and from the tram stop to the end destination, including the train ride to Warsaw city center and transfer to tram), and the 4-segment travel chain: car-train-tram-walk (beginning with a car ride to the train station using the P\&R system, and including the train ride to the center of Warsaw, transfer to tram, and walking to the end destination).

Each of the surveyed travel chains can be illustrated on the figure presenting travel as a time and speed curve divided into particular segments. This survey allows identification of time losses within the transfer node (for example, waiting time for train). Examples of such figures are presented for travel chains: car-train-tram-walk. 


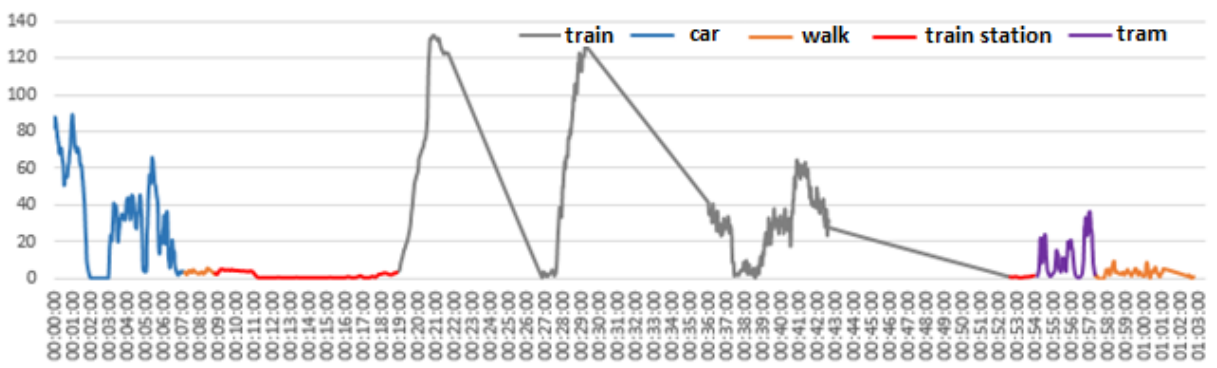

Fig. 1. Passing speed $[\mathrm{km} / \mathrm{h}]$ in time [hh:mm:ss] from origin to destination of travel by travel segments: cartrain-tram-walk.

\subsection{TRAVEL TIME}

Travel chains were examined in terms of components of time, distance, and estimated travel costs. It was found that in complex travel chains there is one dominant segment represented by one of public transport systems (rail or bus). The remaining segments play complementary functions. This is reflected in the components of traveling time. When travel chains are rail-based, the train journey takes up between $44 \%$ and $55 \%$ of total travel time. When buses are used, this component is more prominent $-87 \%$. Complementary segments (i.e. walking, riding by car or tram to the station) amount to $8 \%$ to $20 \%$ of total travel time. The exception is cycling; the percentage of which in total travel is approx. $34 \%$. These surveys made it possible to identify time losses regarding transfers as well, understood as time spent at transfer nodes, including waiting time, time spent walking to the stop within the transfer node, etc. For rail travel this time represents up to $25 \%$ of the entire travel time.

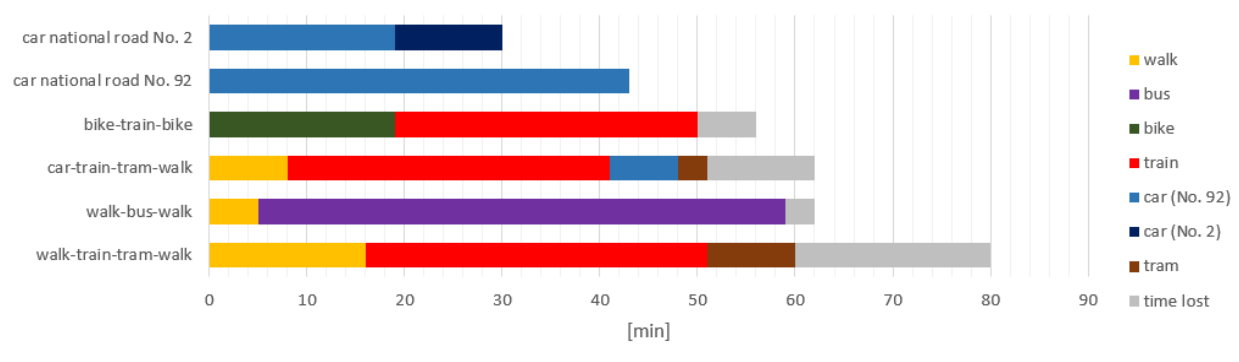

Fig. 2. Diagram of travel time components in selected travel chains [min]. 


\subsection{TRAVEL DURATION}

The amount of time spent on public transport is a basic component of complex chains, as it relates to the duration of travel. The time of travel by train takes from $83 \%$ to $86 \%$ of the total duration of the trip. In the case of walk-bus-walk chains, the bus component is even higher, approx. $99 \%$. Complementary segments such as walking, car rides to rail stops, or tram rides, take from $1 \%$ to $12 \%$ of the total trip duration, while those associated with bicycle use are slightly more notable, i.e. $14 \%$.

Comparing figures representing travel time and length, it was found that travel chains with the shortest travel time are associated with the longest trip duration. This means that longer trips foster selection of travel chains guaranteeing higher travel speed.

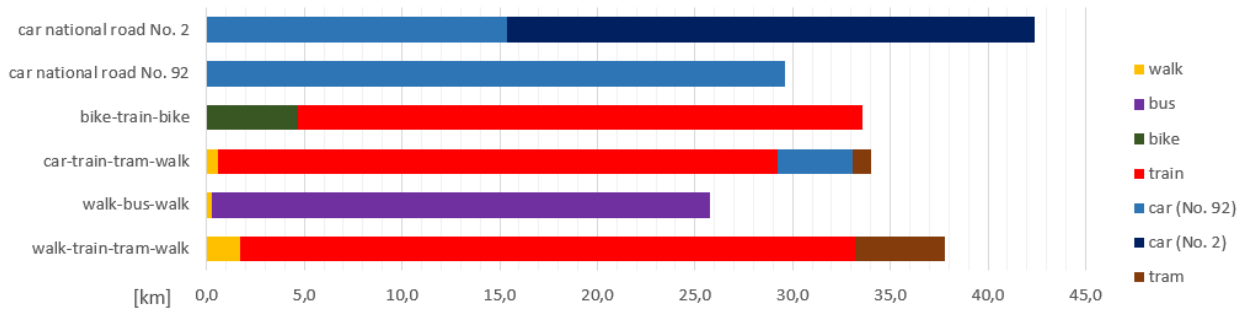

Fig. 3. Diagram of travel length components in selected travel chains $[\mathrm{km}]$.

\subsection{AVERAGE TRAVEL SPEED}

The surveys revealed that traveling by car on a high speed road (motorway) results in an increase in trip length, because it allows the commuter to achieve much better average speed; approx. $82 \mathrm{~km} / \mathrm{h}$. This results in the shortest travel time, approx. $30 \mathrm{~min}$. However, travel by car on lower-class roads (regional) amounts to lower average speeds, averaging $41 \mathrm{~km} / \mathrm{h}$. For comparison, the average travel speed in rail-based chains varies from $28 \mathrm{~km} / \mathrm{h}$ to $36 \mathrm{~km} / \mathrm{h}$, with the highest average speed in cases of rail+bike travel chains. The lowest travel speeds are observed in metropolitan bus trips, only $25 \mathrm{~km} / \mathrm{h}$. 


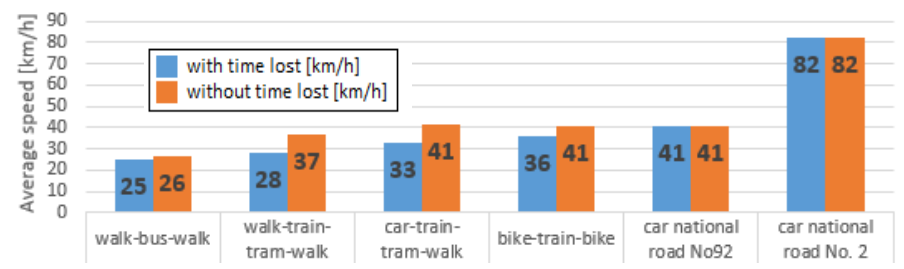

Fig. 4. Average speed $[\mathrm{km} / \mathrm{h}]$ in selected travel chains, with and without time lost.

It was also observed that in the event of minimization of time losses at transfer nodes a noticeable increase of average speed is possible in travel chains using public transport, especially the rail. In this case, an average speed of $41 \mathrm{~km} / \mathrm{h}$ is feasible, quite similar to the average speed achieved by cars using regional roads. Reductions of time losses in travel based on metropolitan buses results in insignificant speed increases from $25 \mathrm{~km} / \mathrm{h}$ to $26 \mathrm{~km} / \mathrm{h}$. Thus, the surveys confirmed some potential in the improvement of rail interchanges, which can profit in an increase in competitiveness of rail transport in relation to cars. For metropolitan buses the story is different; their low competitiveness stems largely from the loss of time accumulated along bus routes. Taking into consideration the current level of bus priorities in traffic schemes, the chance for this mode of transport to obtain the average travel speed comparable to that of cars seems impossible, especially in cases of motorways.

\subsection{TRAVEL COST}

For selected travel chains, user travel costs were analyzed, taking into account costs of tickets and operational costs associated with cars according to [9], without taking into consideration costs of parking, travel time costs, and assuming the vehicle occupancy rate is 1.35 . The highest costs of travel have been attributed to direct car travel $(0.85 \mathrm{PLN} / \mathrm{km})$, and the lowest to bus travel chains $(0.14 \mathrm{PLN} / \mathrm{km})$. Traveling by train turned out to be slightly more expensive, amounting to $0.15-0.17$ $\mathrm{PLN} / \mathrm{km}$, but only the car + train + tram + foot combined trip was a bit more expensive at 0.31 PLN $/ \mathrm{km}$.Analysis showed that combined travel involving public transport is five times cheaper than direct travel by car. Combined car-train travel slightly increases costs, but is still over two times cheaper than travel exclusively by car.

\section{DISCUSSION OF RESULTS}

In the morning hours $(6: 30-7: 30 \mathrm{am})$ the majority of commuter trips from Błonie to the center of the metropolis are carried out by public transport (66\% of trips). Complex travel chains dominate, and 
public transport, in particular trains, is responsible for the main journey segment. Moreover, travel chains involving trains are more complex in comparison to those by metropolitan bus. In such a chains, walking dominates the first segment of the trip between home and a transfer node $-68 \%$ in rail chains, and $99 \%$ in bus chains. The vast majority of walking and riding to a train stop $(80 \%)$ is concentrated within a radius of $3.2 \mathrm{~km}$. $94 \%$ of pedestrian walks to the bus stop do not exceed 1.6 $\mathrm{km}$, whereas $87 \%$ of trips by car to the train stop exceed $1.6 \mathrm{~km}$. Bus stops cover a much smaller impact area $-61 \%$ of pedestrian walks fall within a radius of $0.5 \mathrm{~km}$. In morning peak hours travel chains based on public transport are competition for direct car travel. This applies to the average travel speed of $37-41 \mathrm{~km} / \mathrm{h}$ and low travel costs (from about 5 PLN to 6.5 PLN per trip, by car from around 24.5 PLN to 35.5 PLN per trip). It should be noted [3] that generalized costs of travel should also take into account the cost of time, travel comfort, and safety, however estimating these values is extremely difficult.

It appears that in travel chains based on public transport the best average speed is guaranteed by the bike-train-bike chain (average speed $36 \mathrm{~km} / \mathrm{h}$, with possible increase to $40-41 \mathrm{~km} / \mathrm{h}$ in cases of reduction of time losses during transfers). The walk-bus-walk chain is the cheapest with a total trip cost of 3.50 PLN. It should be noted that public transport competitiveness is strongly dependent on the quality of the alternative road system. In the surveyed case (average car speed on the motorway being $82 \mathrm{~km} / \mathrm{h}$ ) it decreased drastically. However, such traffic conditions are not the rule. Average speeds in other metropolitan cities for passenger cars are much lower, for example in the greater Paris region even several times lower [3].

\section{CONCLUSIONS}

Expansion of road systems in metropolitan areas, especially high-standard roads (motorways, expressways), improves conditions for car travel and discourages the public from using public transport. This favors direct travel from origin to destination (for example, the increase of average travel speed from Błonie to Warsaw from 40 to $80 \mathrm{~km} / \mathrm{h}$ ). This is not, however, possible for complex transport chains based on public transport. Such cases should be considered undesirable and jeopardizing the role of commuter public transport. Moreover, the expansion of high-standard roads in the immediate vicinity of the central city extends the length of car travel, which could result in an increase in adverse environmental impacts.

This research confirmed the importance of the improvement of the quality of transfers carried out within transport nodes in order to ensure the punctuality of public transport and reduction of time 
losses. This creates significant opportunities for the growth of average speeds in complex travel chains, up to speeds similar to the average travel speeds attainable by individual transport (using lower-class roads not motorways or expressways).

The analysis showed that commuter trips, particularly during peak hours, are based on complex chains and deserve to be analyzed and researched in order to identify better the mechanisms of transport systems and means of transport use in travel.

Further studies on travel chains are advised, including analysis of the full range of trips taken during the day (all trip motivations), different weekdays, different months and seasons. This would make it possible to understand periodic and seasonal variation of traffic in the future. It is also necessary to expand the testing area in order to compare the behavior of transport users in other rail corridors (for example, with different qualities of competing road systems) and in different metropolitan areas. Ultimately, the surveys should be combined with the construction of traffic models for metropolitan areas, which would allow for the practical application of knowledge about travel chains.

\section{REFERENCES}

1. Publication of the project Catch-MR (Cooperative approaches to transport challenges in Metropolitan Regions) „Moving People: Towards sustainable mobility in in European Metropolitan Regions” Potsdam 2012.

2. Grzegorz Sierpiński „Zachowania komunikacyjne osób podróżujących a wybór środka transportu w mieście” Prace Naukowe Politechniki Warszawskiej, Warszawa 2012.

3. Yeh Chao-Fu „A study on feasibility of passenger intermodal transport in city of the developing world" Paris University XII \& French National Institute for Transport and Safety Research (INRETS)

4. K. Jesionkiewicz-Niedzińska: „Charakterystyka i efektywność podróży w codziennych dojazdach do aglomeracji miejskiej” [in Polish]. Monografia Wybrane Interdyscyplinarne zagadnienia Budownictwa, Oficyna Wydawnicza PW 2015.

5. Studium wykonalności projektu „Obsługa komunikacyjna pasma zachodniego województwa mazowieckiego w korytarzu: m.st. Warszawa dzielnica Bemowo, Stare Babice- Ożarów Maz.- Leszno- Błonie- KampinosSochaczew", Kraków 2014.

6. Brzeziński A., Dybicz T., Jesionkiewicz-Niedzińska K., Znaczenie systemu P+R na liniach kolejowych w aglomeracji Warszawskiej. Zeszyty Naukowo-Techniczne SITK w Krakowie. Seria Materiały konferencyjne nr 1 (100/2013), Kraków 2013.

7. P. Olszewski, „Ocena przestrzeni publicznej z punktu widzenia pieszych” [in Polish]. Konferencja Miasto i Transport, Warszawa 2007.

8. A. Brzeziński, K. Jesionkiewicz-Niedzińska, „Łańcuchy podróży pasażerskich” [in Polish]. Logistyka 2014.

9. Niebieska Księga, infrastruktura drogowa, Jaspers, Warszawa 2008. 


\section{LIST OF FIGURES AND TABLES}

Fig. 1. Passing speed [km/h] in time [hh:mm:ss] from origin to destination of travel by travel segments: cartrain-tram-walk.

Rys. 1. Prędkości chwilowe [km/h] odniesione do upływu czasu [hh:mm:ss] licząc od rozpoczęcia podróży w podziale na segmenty podróży: samochód-kolej-tramwaj-pieszo.

Fig. 2. Diagram of travel time components in selected travel chains [min].

Rys. 2. Wykres składowych czasu podróży [min] w wybranych łańcuchach podróży.

Fig. 3. Diagram of travel length components in selected travel chains $[\mathrm{km}]$.

Rys. 3. Wykres składowych długości podróży $[\mathrm{km}]$ w wybranych łańcuchach podróży.

Fig. 4. Average speed $[\mathrm{km} / \mathrm{h}]$ in selected travel chains, with and without time lost.

Rys. 4. Wykres średnich prędkości [km/h] w wybranych łańcuchach podróży, z i bez czasu traconego. 


\section{MODELE PODRÓŻY W KORYTARZACH OBSZARÓW METROPOLITARNYCH OBSLUGIWANYCH KOLEJĄ}

Słowa kluczowe: modelowanie podróży, analiza ruchu, łańcuchy podróży, transport zbiorowy, prędkości i długości podróży, suburbanizacja.

\section{STRESZCZENIE:}

W ostatnich latach w miastach obserwowane są niekorzystne procesy suburbanizacji. Powstrzymanie rozpraszania się zabudowy stanowi poważne wyzwanie dla urbanistów i planistów transportu gdyż w znacznej mierze zależy od tego jakość przestrzeni, jakość życia jaki i koszty funkcjonowania miast.

Początkowo rolę głównego stymulatora osiedlania się w pewnej odległości od miasta centralnego pełniła kolej. Stanowiła ona ważny czynnik kształtowania obszarów metropolitarnych. Stacje i przystanki kolejowe wywoływały zainteresowanie lokalizowaniem zabudowy o zwartym charakterze, w naturalny sposób ograniczając rozmieszczenie i skalę suburbiów. Wraz $\mathrm{z}$ rozwojem motoryzacji indywidualnej znaczenie kolei spadło i nastąpił okres niekontrolowanego rozlewania się miasta w konsekwencji presji na rozwój układu drogowego.

Utrzymująca się od lat wysoka dostępność samochodu powoduje, że próby ratowania sytuacji, np. poprzez zwiększanie atrakcyjności oferty transportu zbiorowego są często skazane na niepowodzenie i nie przynoszą zamierzonego skutku. Wynika to m.in. z rozproszenia zabudowy, które jest na tyle duże, że obsługa transportem zbiorowym staje się nieopłacalne z uwagi na koszty obsługi i relatywnie niskie efekty. Szansą jest integrowanie obu systemów transportowych tj. wykorzystanie zalet transportu indywidualnego w części podróży odbywanej w obszarze o małej intensywności zabudowy (gdy podróże są rozproszone w obszarze) i transportu zbiorowego tam gdzie jego efektywność jest uzasadniona liczbą podróżujących (gdy podróże są skupione w korytarzu transportowym). W efekcie prowadzi to do powstawania złożonych modeli podróży, związanych z dokonywania przesiadek pomiędzy różnymi systemami transportowymi, tzw. podróży łączonych, pozwalających efektywniej wykorzystać istniejący system transportowy a w szczególności podsystemy transportu zbiorowego.

Referat poświęcono modelom podróży w obszarach obsługiwanych koleją a jako poligon doświadczalny wybrano gminę Błonie będącą częścią Obszaru Metropolitarnego Warszawy (OMW). W referacie przedstawiono wyniki badań wykonanych w roku 2014 w godzinach szczytu porannego, w szczególności: badania funkcjonowania przystanków kolejowych i autobusowych, badania ilościowe (natężenia użytkowników w poszczególny systemach transportowych) oraz szczegółowe badania podróży złożonych z wykorzystaniem lokalizatorów GPS.

Badania podróży wykonywanych z Błonia do Warszawy wykazały, że większość przesiadek jest związana z koleją, rzadziej z autobusem Zidentyfikowano pięć najważniejszych łańcuchów podróży w relacji Błonie-Warszawa, jednosegmentową podróż odbywaną samochodem (podróż bezpośrednią) oraz cztery wielosegmentowe (podróże łączone) tj.: pieszo + autobus, samochód + kolej, rower + kolej oraz pieszo + kolej. Łańcuchy te poddano szczegółowemu rozpoznaniu, polegającemu na cyklicznej rejestracji położenia użytkowników transportu skorelowanej $\mathrm{z}$ informacją o aktualnie wykorzystywanym środku transportu. Badaniami objęto dojazdy do pracy w szczycie porannym.

W wyniku przeprowadzonych analiz m.in. stwierdzono, że:

1. W szczycie porannym przeważają złożone łańcuchy podróży, w których główny segment stanowi przejazd transportem zbiorowym, w szczególności koleją. Zauważono, że łańcuchy podróży funkcjonujące $z$ 
wykorzystaniem kolei są bardziej złożone w stosunku do tych w których wykorzystywana jest komunikacja autobusowa. W złożonych łańcuchach pierwszy segment podróży, pomiędzy domem a węzłem przesiadkowym najczęściej stanowi dojście piesze - 68\% w przypadku kolei i 99\% w przypadku komunikacji autobusowej.

2. Zdecydowana większość ( $80 \%$ ) dojść i dojazdów do przystanku kolejowego koncentruje się w promieniu 2,5km, przy czym 94\% dojść pieszych do przystanku nie przekracza 1,6 km, a 87\% dojazdów samochodem do przystanku kolejowego przekracza 1,6 km. Przystanki autobusowe mają znacznie mniejszy zasięg odziaływania - $61 \%$ dojść pieszych zawiera się w promieniu $0,5 \mathrm{~km}$.

3. W godzinie szczytu łańcuchy podróży w których wykorzystywana jest kolej są konkurencyjne dla podróży bezpośrednich odbywanych samochodami. Dotyczy to średnich prędkości podróży na poziomie $37-41 \mathrm{~km} / \mathrm{h}$ jak i niskich kosztów podróży od ok 5 zł to 6,5 zł za podróż (samochodem od ok. 24,5 zł do 35,5 zł za podróż). Należy jednak zastrzec, że konkurencyjność kolei jest silnie uzależniona od jakości alternatywnego układu drogowego.

4. W łańcuchach podróży w których wykorzystywany jest transport zbiorowy najbardziej efektywny okazał się łańcuch rower-pociąg-rower (średnia prędkość $36 \mathrm{~km} / \mathrm{h}$ z możliwością podwyższenia po ograniczeniu czasu traconego na przesiadki do ok. 40-41 km/h. Najtańszym okazał się łańcuch pieszo-autobus-pieszo z kosztem podróży na poziomie $3,50 \mathrm{zł}$.

5. Rozbudowa układu drogowego w obszarze metropolitarnym, zwłaszcza dróg o wysokim standardzie (autostrady, drogi ekspresowe) poprawia warunki dojazdu samochodem i prowokuje do rezygnowania z transportu zbiorowego na rzecz podróżowania od źródła do celu podróży w sposób bezpośredni (przykład wzrostu średnich prędkości podróży z Błonia do Warszawy z 40 do nawet $80 \mathrm{~km} / \mathrm{h}$ !!!). Jest to oferta nieosiągalna dla rozbudowanych łańcuchów transportowych, funkcjonujących w oparciu o transport zbiorowy. Jest to niekorzystne i zagraża roli transportu zbiorowego w obsłudze metropolii. Rozwój dróg wyższych klas w bezpośrednim sąsiedztwie miasta centralnego wydłuża długości podróży realizowane transportem indywidualnym, co może oznaczać zwiększenie niekorzystnych oddziaływań środowiskowych.

6. Badania wskazują, że istotne znaczenie może mieć poprawa jakości przesiadek realizowanych w ramach węzłów przesiadkowych oraz zapewnienie punktualności transportu zbiorowego i skrócenie czasu traconego na przesiadkę. Stwarza to szanse zauważalnego wzrostu średnich prędkości w rozbudowanych łańcuchach podróży, do poziomu zbliżonego do średnich prędkości podróży występujących w transporcie indywidualnym (z wykorzystaniem dróg niższej klasy niż autostrady i drogi ekspresowe). 
